\title{
Influence of woodland cover on habitat selection and reproductive parameters of tropical roseate terns: implications for colony management
}

\author{
David Monticelli ${ }^{1,2, *}$, Jaime A. Ramos ${ }^{3}$, Jean-Louis Doucet ${ }^{2}$ \\ ${ }^{1}$ Royal Belgian Institute of Natural Sciences, Section of Conservation Biology, 29 Rue Vautier, 1000 Brussels, Belgium \\ ${ }^{2}$ Laboratory of Tropical and Subtropical Forestry, Unit of Forest and Nature Management, Gembloux Agricultural University, \\ 2 Passage des Déportés, 5030 Gembloux, Belgium \\ ${ }^{3}$ Institute of Marine Research (IMAR), Department of Zoology, University of Coimbra, 3004-517 Coimbra, Portugal
}

\begin{abstract}
We examined the effect of vegetation structure, in particular canopy closure, on colony site occupancy, nesting densities, and reproductive parameters of roseate terns Sterna dougallii breeding in a Pisonia grandis dominated woodland on Aride Island, Seychelles, western Indian Ocean. Long-term observations (1995 to 2006) revealed that areas with high vegetation density and canopy cover ( $>50 \%$ ) were abandoned, in favour of nearby more open forest areas, such as clearings. The attractiveness of a forest clearing ( 0 to $25 \%$ canopy cover) to breeding birds was also largely supported by experimental manipulation of vegetation density in 2004. Most birds moved from areas under canopy cover to experimentally cleared plots, where they nested at higher densities and had a higher probability of successfully fledging a chick. However, some individuals remained in their original areas, despite their greater canopy cover, and had a lower fledging success. This site tenacity is presumably explained by an imprinting process leading some birds to breed in successive years in the same, familiar locations, despite their nest-sites having become sub-optimal for fledging success. Roseate terns choosing a nest site in woodland on Aride must trade off the need for some cover, offering protection from the sun, against the need for easy access through gaps in the canopy to fly to and from their nests. A suitable nest-site should also minimize chick/parent infestation by ticks and mortality caused by contamination of feathers with the sticky fruits of Pisonia grandis. We suggest that, when they are not formed naturally, small artificial forest clearings within the usual breeding area are likely to be attractive for roseate terns and may result in enhanced colony productivity. These findings may be applicable to other seabird colonies (e.g. sooty terns) found under forest cover on oceanic islands throughout the Indo-Pacific region.
\end{abstract}

KEY WORDS: Seabird colonies - Sterna dougallii $\cdot$ Habitat preference $\cdot$ Western Indian Ocean Canopy cover $\cdot$ Pisonia grandis

Resale or republication not permitted without written consent of the publisher

\section{INTRODUCTION}

Spatial variation in habitat conditions promotes a strong selective pressure for habitat choice (Cody 1985), thereby producing a non-random distribution of animals among available habitats. Several studies have shown that habitat attributes apparently selected by birds often correspond to habitat occupancy patterns and higher breeding success (Sergio \& Newton
2003, Johnson 2007). This is not always the case, however, because birds are vulnerable to changes in habitat characteristics that they may be unable to predict (Blondel et al. 1993, Battin 2004).

Most ground-nesting seabirds breed in open areas (Schreiber \& Burger 2001), but populations of some species, such as sooty terns Sterna fuscata (Feare et al. 1997), yellow-eyed penguins Megadyptes antipodes (Seddon \& Davis 1989), brown boobies Sula leuco- 
gaster (de Korte 1984) and tropicbirds Phaeton spp. (Clark et al. 1983, Schreiber \& Burger 2001) may nest under the shelter of a tree canopy or under shrubs. Tree cover may provide protection against the sun, inclement weather conditions and predators, but an increasing canopy closure may cause some difficulties to tropical seabirds, such as sooty terns, when attempting to fly to and from their nests (Feare et al. 1997). A few studies have addressed the influence of vegetation cover on nesting density and nest-site selection (e.g. Saliva \& Burger 1989, Feare et al. 1997), but the influence of forest characteristics on both breeding habitat selection and the reproductive performance of seabirds that nest under a tree canopy has received little attention, especially in tropical species.

The roseate tern Sterna dougallii is a widely but sparsely distributed seabird with its global stronghold in the Indian Ocean (Gochfeld 1983). A peculiar trait of breeding roseate terns on Aride Island (a 73.2 ha nature reserve), Seychelles, is their apparent preference to nest on open leaf litter beneath a tree (Pisonia grandis) canopy (Warman 1979), contrasting with their usual relatively open nesting habitat, consisting of sand and rock with sparse herbaceous vegetation in other tropical areas (Burger \& Gochfeld 1988, Shealer 1995). Historical accounts suggest that Pisonia trees were coppiced annually on Aride until 1967 to provide space for ground nesting seabirds (Warman \& Todd 1984), an action probably targeted particularly at sooty terns whose eggs were harvested as a human food source.

In 1975, an estimated 4300 to 4800 pairs of roseate tern nested on Aride (Warman 1979), but this has now dropped to between 600 and 1300 (Ramos et al. 2002). The roseate tern was considered globally near-threatened (sensu IUCN criterion) until fairly recently, owing to a dramatic extinction of known colonies over the last half century (Collar \& Andrew 1988). A more recent update showed that population levels appeared to have stabilized, and the species was removed from the Red List in 2004 (BirdLife International 2004). The Aride population is of regional and global importance, as the species is poorly represented elsewhere in the western Indian Ocean (Ramos 2002a), with few other breeding localities currently identified (Tree 2005). The main factors currently known to limit colony productivity on Aride are periods of unpredictable food shortage causing chick starvation in some years (Ramos 2002a), and the infestation of chicks by the hard tick Amblyomma loculosum, which has a detrimental effect on chick body condition and survival (Ramos et al. 2001).

The Aride 'woodland colony' was first described by Warman (1979), who reported that roseate terns prefer nesting under tall woodland cover with several metres of unimpeded airspace under the tree canopy. In 1995, Maul (1998) recorded a high nesting density where trees had fallen after a storm (canopy gap). A detailed sketch of site occupancy made in subsequent years revealed that previously colonized areas were progressively abandoned and, by 2004, the colony-site was virtually restricted to about half of the original area (Monticelli \& Ramos 2004). Annual population counts made over the same period (1995 to 2004) showed that the breeding population was fairly stable (Ramos et al. 2002, Ramos \& Monticelli 2007), suggesting that changes in forest characteristics may be involved in shaping the spatial distribution of the woodland colony.

In the present paper, we studied the influence of woodland vegetation structure on the spatial distribution of breeding roseate terns and on their reproductive parameters on Aride Island by focusing on the following: (1) comparing canopy cover and other vegetation characteristics between the breeding area used in 2004 to 2005 and other areas previously colonized by the birds but currently unused (i.e. used in 1995 to 2003), (2) manipulating habitat features within the abandoned areas (experimentally cleared plots) to monitor the response of birds in subsequent years, and (3) monitoring breeding success and other reproductive parameters in the colony (2004 to 2005) within 2 areas differing in forest conditions (clearing vs. closedcanopy quadrats) and nest density. We predicted that nest density should be lower under canopy cover, as previously found for sooty terns on Aride (Feare et al. 1997), and that breeding success would be reduced in areas with dense canopy cover, when compared to more open (clearing) areas. This could be explained by (1) birds having to make more elaborate flight manoeuvres to reach their nest under a closed tree canopy, which may result in a lower feeding rate of the chicks and ultimately decrease fledging success and/or (2) a higher proportion of chicks infested by ticks in closed canopy areas due to damper conditions that favour tick survival (Peavey \& Lane 1996). Our results are discussed with a view to providing conservation measures for seabirds nesting under a forest canopy.

\section{MATERIALS AND METHODS}

Study area. Aride Island $\left(4^{\circ} 10^{\prime} \mathrm{S}, 55^{\circ} 40^{\prime} \mathrm{E}\right)$, Seychelles, hosts one of the largest tropical roseate tern populations in the western Indian Ocean (Tree 2005). Over the last 10 yr (1995 to 2006), breeding numbers have fluctuated irregularly, with a maximum of ca. 1300 pairs in 1996 and 1999 (Ramos et al. 2002, Ramos \& Monticelli 2007). The birds nest from May to 
July on the forest floor in a main colony estimated to cover ca. 0.20 ha in 1995, and located about $150 \mathrm{~m}$ inshore (ca. $100 \mathrm{~m}$ above sea-level, on a hill slope of ca. 15 to $20 \%$ ). Small, discrete groups of birds were also irregularly found breeding in sub-colonies on the forest floor or on the open rocky shore of the island. The woodland vegetation consists mainly of mature stands of Pisonia grandis (<20 m tall; Feare et al. 1997), but other tree species include Ficus reflexa and F. nautarum. The understorey comprises shrubs such as Euphorbia pyrifolia ( $<6 \mathrm{~m}$ tall), and a small tree, Rothmannia annae (<8 $\mathrm{m}$ tall), which is endemic to Aride (Castle \& Mileto 1994). The ground beneath the canopy is largely unvegetated (open leaf litter) but covered in places with herbs (Feare et al. 1997).

Vegetation plots and manipulations. From 1995 onwards, the area covered by the nests was sketched on a map at the time of the annual census (16 to $18 \mathrm{~d}$ after the first egg was laid; Ramos 2002a) and delimited in the field by permanently marking rocks with painted numbers (Maul 1998). Major changes in colony boundaries were observed in 2000 and 2004 (Fig. 1). In 2004, we placed a grid of $5 \times 5 \mathrm{~m}$ plots in the abandoned area of the colony, within which 16 plots were selected: 10 plots within the area used between 1995 and 1999 (i.e. abandoned in 2000), and 6 plots in the area more heavily used by the birds until 2003 (i.e. abandoned in 2004; Fig. 1). All plots were delimited in the field with posts and string for measurements of vegetation structure. Within the breeding space occupied in 2004 (Fig. 1), we restricted our investigations to 4 other vegetation plots in order to keep disturbance of nesting birds to a minimum: 3 plots (nos. 17 to 19) were marked in the centre of a large canopy gap heavily used by the birds, whereas one plot was established at the periphery of this natural clearing (Plot 20; Fig. 1). These last 4 plots were permanently marked and revisited in 2005 and 2006 to measure canopy cover.

In addition, of the 16 plots marked in 2004 within abandoned breeding areas, 2 (nos. 15 and 16) were experimentally cleared several months before the 2005 breeding season (March 2005) by coppicing Pisonia trees to create a $50 \mathrm{~m}^{2}$ clearing. Both plots were revisited in 2005 and 2006 to measure canopy cover, other vegetation characteristics (2005 only) and roseate tern nesting density.

Measurement of vegetation variables. In each plot, we estimated (1) the density of stems and shrubs, (2) the basal area, (3) the canopy closure, (4) the intensity of the understorey vegetation (vegetation volume), and (5) the ground cover of herbaceous species (methods and definitions outlined in Table 1). Vegetation intensity of the understorey ( 0 to $6 \mathrm{~m}$ ) was estimated by using a variation of the point quadrat method (ScottMills et al. 1991). A vertical $6 \times 5 \mathrm{~m}$ grid was built on

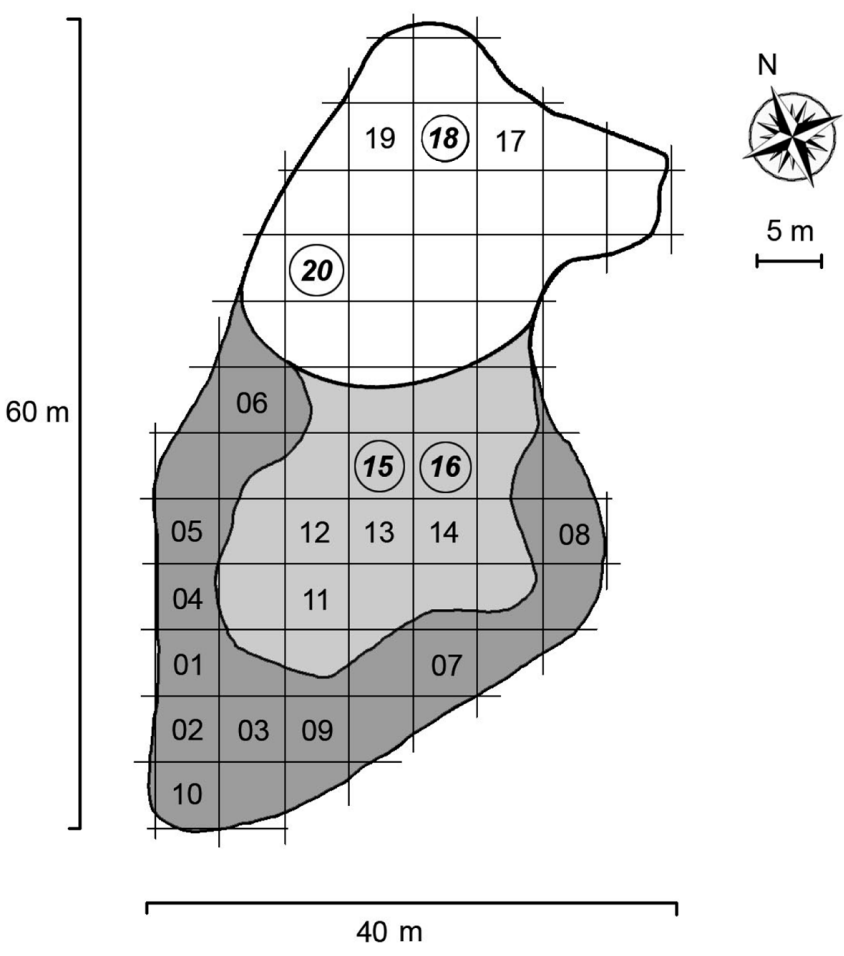

Abandoned since 2000

Abandoned since 2004

Occupied (2004)

Fig. 1. Map of the woodland colony on Aride Island, Seychelles, showing the location of the 20 vegetation plots sampled. Dark gray: area abandoned since 2000, $\mathrm{n}=10$ plots; light gray: area abandoned since 2004, $\mathrm{n}=6$ plots; white: area occupied in 2004, $\mathrm{n}=4$ plots. The overall boundaries represent the area initially colonized in 1995 (Maul 1998). Study quadrats where roseate tern nesting success and reproductive parameters were monitored in 2004 and 2005 are also shown (italic encircled numbers; see text)

the side of each plot (south-western to north-western corner) by using a $6 \mathrm{~m}$ pole marked in metre sections and held vertically at intervals of $1 \mathrm{~m}$. We visually counted the number of $1 \times 1 \mathrm{~m}$ grid-cells that contained vegetation within the plot, and estimated vegetation volume $(\%)$ as $\mathrm{V}=100 \times \mathrm{c} / 30$, where $\mathrm{c}=$ the number of cells where vegetation was present within the plot. Canopy closure (overstory cover) was estimated from a digital photograph taken in the centre of each plot by using a Nikon Coolpix 995 and a fish-eye lens converter mounted on a tripod at a height of $1 \mathrm{~m}$ above the ground and leveled with a spirit level (Englund et al. 2000). Within each plot, we also visually estimated the percentage cover of the 2 fern species Nephrolepis biserrata and Asystasia gangetica, since a dense herb 
Table 1. Vegetation characteristics recorded in $25 \mathrm{~m}^{2}(5 \times 5 \mathrm{~m})$ plots laid in the woodland colony on Aride Island, Seychelles

\begin{tabular}{|c|c|}
\hline Variable (unit) & Description \\
\hline Vegetation volume $(\%)$ & $\begin{array}{l}\text { Vegetation intensity of understorey ( } 0 \text { to } 6 \mathrm{~m} \text { ) } \\
\text { estimated with the point-quadrat method }\end{array}$ \\
\hline Canopy closure $(\%)$ & $\begin{array}{l}\text { Canopy cover estimated with a hemispherical } \\
\text { photograph processed with Gap Light } \\
\text { Analyser }\end{array}$ \\
\hline $\begin{array}{l}\text { Density of stems } \\
\left(\text { no. stems plot }{ }^{-1}\right)\end{array}$ & $\begin{array}{l}\text { Total no. of stems and shrubs }>1.5 \mathrm{~m} \text { tall per } \\
25 \mathrm{~m}^{2} \text { plot }\end{array}$ \\
\hline Basal area $\left(\mathrm{cm}^{2}\right.$ plot $\left.^{-1}\right)$ & $\begin{array}{l}\text { Total surface area at breast height per } 25 \mathrm{~m}^{2} \\
\text { plot calculated from } \Sigma \pi \times(d / 2)^{2}, \text { where } d= \\
\text { diameter at breast height }(1.3 \mathrm{~m}) \text { of tree } \\
\text { stems }>1.5 \mathrm{~m} \text { tall }\end{array}$ \\
\hline Fern cover $(\%)$ & $\begin{array}{l}\text { Nephrolepis biserrata and Asystasia } \\
\text { gangetica cover estimated visually }\end{array}$ \\
\hline Herbaceous cover $(\%)$ & Other herbaceous cover estimated visually \\
\hline
\end{tabular}

clearing (clearing-quadrat: Plots 15 and 16; Fig. 1), while the canopyquadrat was re-located as Plot 20, which was now under denser woodland cover compared to 2004 (Fig. 1). Nesting densities were assessed by counting all active nests in our study quadrats at the time of peak laying (May to June).

In both years, nests were marked in the study quadrats with numbered wooden pegs, clutch size (1 or 2 eggs) was recorded and eggs were numbered using a permanent dye. Egg external volume $\left(V, \mathrm{~cm}^{3}\right)$ was calculated from egg length $(L, \mathrm{~cm})$ and breadth $(B, \mathrm{~cm})$ measured to the nearest $0.1 \mathrm{~mm}$ with calipers using $V=$ $0.512 \times L \times B^{2}$ (Stonehouse 1966). Egg

layer of these plants may cause roseate terns to abandon breeding areas (Ramos 2002a). If other herb species were present, their cover was also estimated visually, since vegetative cover represents a typical feature selected by roseate terns breeding in the open (Ramos 1998).

Hemispherical photographs were processed with Gap Light Analyser (Frazer et al. 1999). The truecolour image was first converted to binary (white and black pixels) by using a threshold fixed by the user. The appropriate threshold was determined visually by comparing binary images obtained for different threshold values to the original image. The binary image for which all holes in the canopy were adequately represented was retained (Englund et al. 2000) and for photographs taken under similar sky conditions (i.e. the same day) the same threshold was applied. A canopy openness value in \% (canopy cover $=100-$ canopy openness) was calculated as the total number of white pixels.

Sampling roseate tern breeding success and reproductive parameters. In 2004, 2 quadrats were located in the area densely colonized by the birds, where our vegetation plots were also selected (Plots 18 and 20; Fig. 1), to monitor nest success and other reproductive parameters. Each quadrat was centred on the vegetation plot, but extended to a $49 \mathrm{~m}^{2}$ surface area $(7 \times 7$ instead of $5 \times 5 \mathrm{~m}$ ) in order to increase the number of nests sampled. The first quadrat was established under woodland cover (canopy-quadrat: Plot 20; Fig. 1), and the second quadrat was laid ca. $20 \mathrm{~m}$ away from it in the centre of a naturally-formed clearing, where a tree had fallen before the breeding season (clearingquadrat: Plot 18; Fig. 1). In 2005, we established one $7 \times 7 \mathrm{~m}$ quadrat in the area where experimental vegetation plots were cleared to create artificially a $50 \mathrm{~m}^{2}$ fate (still present, hatched or lost) was recorded at 1 to 3 d intervals during incubation and chicks were ringed at hatching (= Day 0 ) to allow subsequent recapture to assess nestling survival. For broods of 2 chicks, the laying order was inferred from the hatching sequence (a-chick: first laid egg, $b$-chick: second laid egg). Chick fate (dead or alive) and infestation by ticks were recorded through the rearing period, with most surviving chicks monitored until they fledged (25 to $30 \mathrm{~d}$ old; Gochfeld et al. 1998) or until they could no longer be observed. This latter situation generally occurred around 2 to 3 wk post-hatching (i.e. 15 to $20 \mathrm{~d}$ old), when large chicks frequently wandered out of the nesting territory with their parents; those surviving after the linear growth period (4 to $14 \mathrm{~d}$ ) were considered to have fledged if food conditions did not deteriorate shortly (about 2 wk) after they were last encountered (Ramos 2001). All chicks with attached ticks were noted. At the end of the breeding season, we checked the whole colony for chick corpses and for rings that could have fallen off dead chicks.

Body condition index of adults and feeding rates. In 2005, wing-chord ( $\mathrm{mm}$ ) and body mass ( $\mathrm{g}$ ) were measured on a sample of 26 adults captured at randomly selected nests in each quadrat (clearing and canopy). All captured birds were at a similar nesting stage (chick hatching $\pm 3 \mathrm{~d}$ ) and their body condition index (BCI) was indexed using $\mathrm{BCI}=1-$ (residual $\mathrm{OM}$ )/TM, where OM is the observed mass ( $\mathrm{g}$ ), TM is the body mass predicted by the linear regression of mass against wing-chord, and residual OM = TM OM (Le Corre et al. 2003). A BCI < 1 indicates that the adult is lighter than expected and a BCI $>1$ indicates an adult heavier than expected. We also tested whether chick feeding frequency (no. fish fed/h/ 
chick/nest) varies with nest location, by counting, with the help of binoculars, the number of prey items (mostly goatfishes; Ramos 2000) delivered by parents during the early morning (between 07:00 and 09:00 h). Six nests were selected in each quadrat and their chicks followed for 7 consecutive d (1 to 8 July 2005) during the linear growth period (4 to $14 \mathrm{~d}$ ) from 2 temporary hides located 10 to $15 \mathrm{~m}$ from the monitored nests. All chicks were at a similar stage of development (4 to $7 \mathrm{~d}$ old) to control for the possible influence of age on feeding rate.

Statistical analysis. Canonical discriminant analysis using the 5 vegetation variables (Table 1) was used to differentiate between 3 groups of areas: $\mathrm{A}=$ abandoned since 2000, $\mathrm{B}=$ abandoned since 2004 and $\mathrm{C}=$ occupied in 2004 and 2005 (see 'Results'). The analysis was made on transformed variables; arcsine transformation was employed on \% variables and a squareroot transformation on counts. Discriminant analysis was used as an exploratory tool and the \% of scores classified correctly into their respective group was used to indicate the effectiveness of the canonical discriminant analysis (Williams 1983).

Generalized Linear Model (GLM) procedures (Type III sum of squares) were used to examine the effect of the following explanatory variables: type of cover (canopy vs. clearing-quadrats), nest density (no. nests/m²/quadrat) and year (2004 vs. 2005) on both the response variables egg volume and hatching date. Nest density and year were entered in the model as a continuous covariate and a categorical random factor, respectively (Zar 1999). For egg volume, we first used a $t$-test to compare egg sizes between single-egg

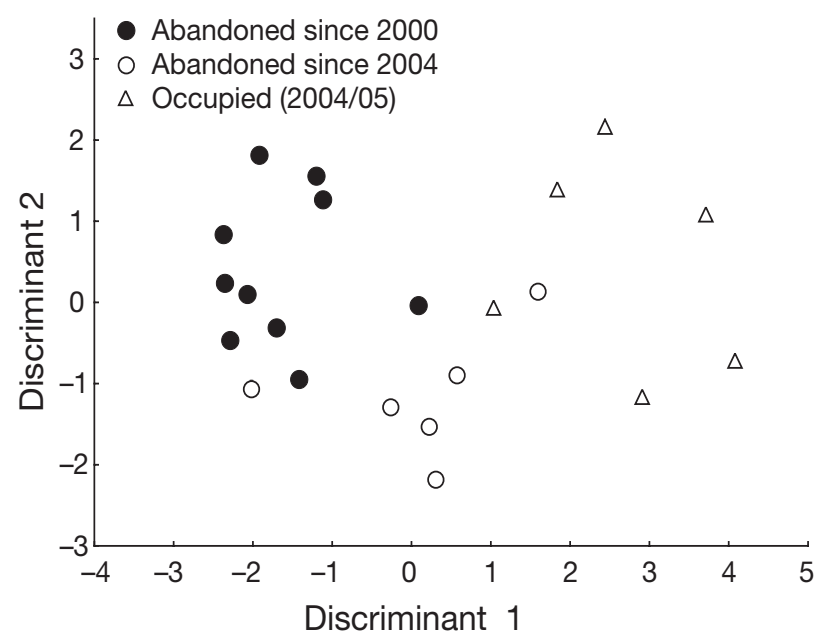

Fig. 2. Scatterplot for the 2 discriminant functions, using vegetation characteristics (see Table 1), to differentiate among occupied breeding areas ( $\mathrm{n}=4$ and 2 plots in 2004 and 2005, respectively) from those areas which had been abandoned since 2000 ( $\mathrm{n}=10$ plots) and 2004 ( $\mathrm{n}=6$ plots) clutches and those of first hatched chicks ( $a$-chicks) in broods of 2, but found no significant differences ( $t$-test, $\mathrm{p}=0.49$ ), so the 2 categories were pooled as a single response variable in the GLM model. Very few $b$ chicks hatched in 2005, so that $b$-egg volumes were not used in the analysis. For the hatch date model, we used the hatching date of each chick ( $a-$, $b$-chicks) defined in relation to 1 June $=1$. Logistic regression was used for response variables with a binomial distribution, such as clutch size, hatching success (lost $=0$, hatched $=1$ ), and fledging success (chick dead $=0$, fledged =1). For this latter model, we assessed the effect of 4 explanatory variables: type of cover, year, nest density and tick parasitism (absent $=0$, present $=$ 1). The significance of each coefficient retained in a given model was assessed with $t$-tests (GLM) or Z-tests (logistic regression).

Mean adult body condition and chick feeding rate (log-transformed) were compared between the clearing and canopy-quadrats using $t$-tests. The number of chicks infested with ticks was also compared between the 2 areas with chi-square (with Yates correction). Data were analysed with Statistica and Minitab15 and are presented as mean $\pm \mathrm{SD}$.

\section{RESULTS}

\section{Vegetation characteristics and breeding habitat use}

The 2 plots (15 and 16; Fig 1) located initially in the area abandoned by the birds in 2004 but experimentally cleared in March 2005 were heavily colonized in the following breeding season (June 2005). The canonical discriminant analysis subsequently performed among the 3 plot areas: A (abandoned since 2000), B (abandoned since 2004) and C (occupied in 2004/05) showed that vegetation characteristics differed between groups (ANOVA of discriminant analysis: $F_{12,28}=3.95, \mathrm{p}<0.0013$, Wilk's Lambda $=0.138$, Fig. 2) . The percentage of cases classified correctly into each group was 90,66.6 and 83.3\%, for Groups A, B and C, respectively. The first discriminant function was statistically significant $\left(\chi^{2}{ }_{12}=32.71, \mathrm{p}=0.001\right)$ but the second was not $\left(\chi_{5}^{2}=7.31, \mathrm{p}=0.20\right.$, Fig. 2$)$. The most important variables to discriminate between groups were vegetation volume $(p=0.01$, partial Wilk's Lambda $=0.52)$, and basal area $(\mathrm{p}=0.045$, partial Wilk's Lambda $=0.54)$. Vegetation volume decreased from plot areas A, to B and C, whereas the basal area was larger in plot area B.

Overall, the comparison of vegetation characteristics between the 2004 to 2005 nesting area (C) and those abandoned (A and B pooled) suggested a preference for more open areas (Table 2). 
Table 2. Comparison of vegetation characteristics (mean $\pm \mathrm{SD}$ ) recorded in the woodland colony on Aride Island within the 2004 to 2005 nesting area and at abandoned areas (used from 1995 to 2003). The nesting area consisted of opencanopy habitat such as natural ( $\mathrm{n}=4$ plots) and experimentally created $(\mathrm{n}=2$ plots) clearings. The abandoned areas consisted of habitat previously used between 1995 and 1999, and 1995 to 2003 (Fig. 1; n = 16 plots). Statistical tests were performed on transformed variables

\begin{tabular}{|lccrc|}
\hline Variable (unit) & $\begin{array}{c}\text { Used area } \\
\text { (2004 to 2005) }\end{array}$ & $\begin{array}{c}\text { Abandoned area } \\
\text { (used from } \\
\text { 1995 to 2003) }\end{array}$ & $\begin{array}{c}t \text {-test } \\
\text { (df = 20) }\end{array}$ & $\mathrm{p}$ \\
\hline Vegetation volume (\%) & $19.3 \pm 13.1$ & $66.4 \pm 20.6$ & 4.95 & $<0.001$ \\
Canopy closure (\%) & $27.4 \pm 16.1$ & $50.5 \pm 11.5$ & 3.93 & $<0.001$ \\
Density of stems & $2.5 \pm 2.7$ & $8.6 \pm 2.9$ & 4.93 & $<0.001$ \\
$\quad($ no. stems plot & & & & \\
Basal area $\left(\mathrm{cm}^{-1}\right.$ plot $^{-1}$ ) & $523.5 \pm 821.6$ & $1902.4 \pm 1903.6$ & 2.13 & $<0.05$ \\
Fern cover (\%) & $1.7 \pm 4.1$ & $5.9 \pm 8.4$ & 1.31 & 0.20 \\
Herbaceous cover (\%) & $17.5 \pm 28.2$ & $3.1 \pm 5.7$ & 1.43 & 0.16 \\
\hline
\end{tabular}

2006). In fact, observations of ringed adults whose nests were located in 2004 to 2005 suggest that birds had moved towards the experimental clearing where canopy cover had been artificially decreased from 55 (2004) to $14 \%$ (2005), and 18\% (2006; 1-way ANOVA, $F_{2,3}=26.4, \mathrm{p}=0.012$ ) (Fig. 3). Of 9 ringed adults nesting in the area of our non-manipulated plots in 2004, 6 were relocated nesting in the experimental clearing in 2005, while the remaining 3 were still breeding in the original area. Overall, the number of nests in and around the artificial clearing in 2005 was 469 (about two-thirds of the overall breeding population estimated at 686 nesting pairs).

\section{Permanent plots and canopy cover regrowth}

From the end of the 2004 breeding season onwards, 6 permanent plots comprising 4 non-manipulated plots (17 to 20) and 2 experimentally cleared plots (15 and 16) were investigated to obtain repeated measures of canopy cover. For non-manipulated plots, canopy closure increased dramatically from $35 \%$ in 2004 to 72 and $67 \%$ in 2005 and 2006, respectively (Fig. 3), and a nearcomplete abandonment of this area by nesting roseate terns was observed (1 plot used in 2005 [Plot 20], 0 in

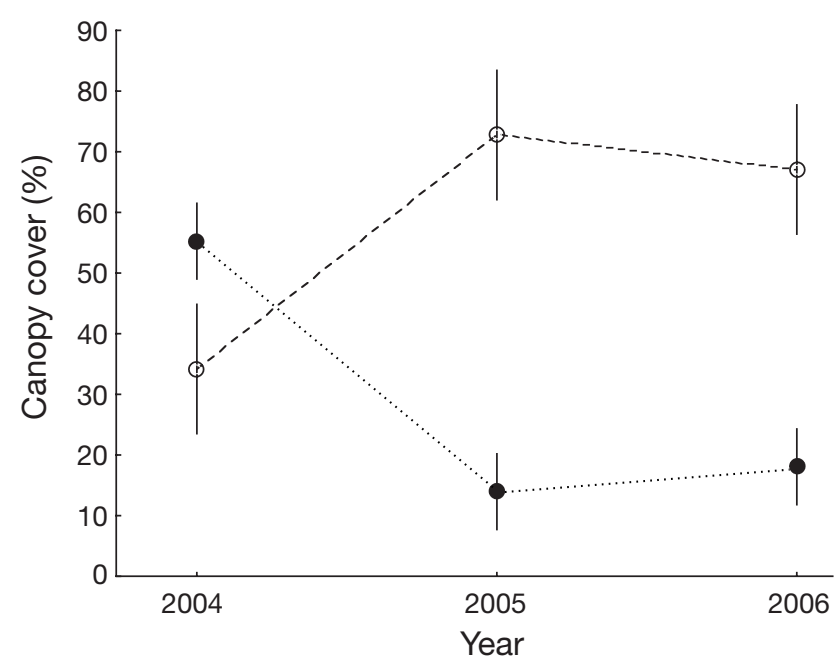

Fig. 3. Percentage canopy closure (mean \pm SD) estimated from hemispherical photographs taken annually in permanent $25 \mathrm{~m}^{2}$ plots followed over a $3 \mathrm{yr}$ period. $\bullet=$ plots abandoned in 2004 but experimentally cleared by coppicing Pisonia trees, and subsequently used by the birds in 2005 to 2006 ( $\mathrm{n}=2$ plots), $\mathrm{O}=$ plots used in 2004 by the birds, but largely abandoned in 2005 and completely deserted by 2006 ( $\mathrm{n}=4$ plots)

\section{Reproductive characteristics and breeding habitat use}

No explanatory variables influenced the logistic regression model of hatching success. Nest density estimated in both natural (Plot 18; Fig. 1) and artificial (Plots 15 and 16; Fig. 1) clearings was 1.13 and 1.42 nests $\mathrm{m}^{-2}$, respectively, which was higher than that found in the quadrat established at the periphery of those clearings, under denser woodland cover (canopy-quadrat [Plot 20]: 0.98 nest $\mathrm{m}^{-2}$ and 0.43 nest $\mathrm{m}^{-2}$ in 2004 and 2005, respectively). Nest density had a significant effect on hatching date, with a tendency for a later mean hatching date within the denser areas (clearing-quadrats; GLM: $F_{1,171}=29.92, p<0.001$; Table 3).

Egg (GLM: Year: $F_{1,190}=4.78, \mathrm{p}=0.03$ ) and clutch sizes varied significantly over the study period with larger clutches and eggs laid in 2004 than in 2005 (Table 3). Moreover, the mean hatching date was also significantly earlier in 2004 than in $2005\left(F_{1,171}=\right.$ 188.37, p < 0.001; Table 3), which altogether suggests better food conditions in 2004 .

We found that larger clutches were laid in the natural and artificial clearings than in the canopy quadrat (Table 3). In 2005, the mean chick feeding frequency did not differ between adults breeding in the artificial clearing and in the enclosed canopy area (clearingquadrat: $1.78 \pm 0.78$, canopy-quadrat: $1.96 \pm 0.43, t_{12}=$ $0.75, \mathrm{p}=0.47, \mathrm{n}=14$ ). Moreover, no difference in mean BCI was detected between adults breeding in both areas (clearing-quadrat: $0.98 \pm 0.07$, canopy-quadrat: $\left.1.02 \pm 0.06, t_{24}=1.56, \mathrm{p}=0.13, \mathrm{n}=26\right)$. Type of cover was a significant predictor of fledging success, with higher values found in the clearings $(63.8 \%)$ than in 
Table 3. Results of general linear (GLMs) and logistic regression (Log. Regr.) models testing the effect of nest density (no. nest(s) $\mathrm{m}^{-2}$ ), type of cover (clearing vs. canopy-quadrats) and year (2004 and 2005) on reproductive parameters of roseate terns on Aride Island, Seychelles. Only models with significant coefficients are shown. Clea: clearing-quadrat, Can: canopy-quadrat

\begin{tabular}{|llcc|}
\hline Response variable & Predictor(s) ${ }^{\text {a }}$ & $t$-test or $Z$-test, $\mathrm{p}$ & Effect level \\
\hline Egg volume (GLM), $\mathrm{n}=194$ & Year & $t=2.19, \mathrm{p}=0.03$ & $2004>2005$ \\
Hatch date (GLM), $\mathrm{n}=175$ & Year & $t=13.72, \mathrm{p}<0.001$ & $2004<2005$ \\
& Nest density & $t=5.47, \mathrm{p}<0.001$ & $+(\mathrm{positive)}$ \\
Clutch size (Log. Regr.), $\mathrm{n}=236$ & Year & $Z=5.83, \mathrm{p}<0.001$ & $2004>2005$ \\
& Type of cover & $Z=2.42, \mathrm{p}=0.013$ & Clea $>$ Can \\
Fledging success (Log. Regr.), $\mathrm{n}=168$ & Type of cover & $Z=2.64, \mathrm{p}=0.008$ & Clea $>$ Can \\
& Tick parasitism & $Z=2.03, \mathrm{p}=0.042$ & $-($ negative) \\
anly significant predictors are presented for each response variable & & \\
\end{tabular}

the quadrat located under denser tree canopy $(38.2 \%$; Table 3). Tick parasitism was also an important factor negatively affecting fledging success (Table 3), but there was no significant difference in the number of chicks infested with ticks between both areas in 2004 (clearing-quadrat: 14.3\%, canopy-quadrat: $24.4 \%, \chi^{2}{ }_{1}=0.97, \mathrm{p}=0.32, \mathrm{n}=121$ ) and 2005 (clearingquadrat: $43.4 \%$, canopy-quadrat: $66.7 \%, \chi^{2}{ }_{1}=1.70, \mathrm{p}=$ $0.19, \mathrm{n}=47$ ).

\section{DISCUSSION}

\section{Spatial distribution of nesting terns}

This is the first study showing that Sternidae breeding under a woodland canopy nest at much higher densities in forest clearings than in closed canopy areas, and that birds move readily to newly formed clearings within the vicinity of the colony area. Our forest clearing experiment showed that roseate tern individuals breeding under a certain forest canopy cover readily moved to a forest clearing in the year following its formation. As nest density is often correlated with habitat quality (Bock \& Jones 2004), this suggests that forest clearings were of higher quality to breeding roseate terns than closed canopy areas.

The discriminant analysis clearly separated areas occupied at the time of the study from those areas abandoned in the previous year and 4 yr ago. The longer the areas were abandoned, the higher was their vegetation cover, in particular vegetation volume. On Aride, forest cover above a natural clearing increased very quickly in the year following its formation (about $35 \%$ ) and then tended to stabilize. Our long-term observations suggest that within about 5 yr of their formation the clearings are too closed, leading to a relocation of breeding roseate terns to a nearby more open forest area. Overall, roseate terns stopped nesting in areas with a canopy cover $>50 \%$. Therefore, as the forest canopy closes in, one can envisage a progressive or sudden abandonment of those forest areas, depending on the rate of the formation of forest clearings. This is illustrated by the progressive abandonment of one sub-colony, which we named Bois Tortue, where 50 pairs in 1987 decreased to 4 pairs in 2001 (Ramos et al. 2002) and 0 in 2004 (Monticelli \& Ramos 2004). Although we did not collect data on forest characteristics there, it was clear that the forest cover on Bois Tortue, situated on a small slope fairly protected from winds, was progressively increasing as the trees and shrubs in the area were growing.

The presence of several large trees within and/or in the vicinity of the breeding area (i.e. open forest canopy) should provide some protection against the sun and poor weather such as heavy rainfall (Burger \& Gochfeld 1988, Ramos \& del Nevo 1995). However, roseate terns breeding in clearings and under low canopy cover should be able to fly in and out of the nesting area more easily than roseate terns breeding under greater canopy cover. We observed that birds breeding in more closed forests need to make elaborate flights when landing and especially when taking off. Birds breeding under high canopy tended to leave their nests later than birds breeding in clearings, especially following a disturbance. However, when canopybirds wanted to leave their nests they did not have a straightforward escape route and thus remained in the potential danger area longer than when nesting in the clearings, a behaviour also observed in sooty terns (C. J. Feare pers. comm.).

Several roseate terns have been found dying as a result of entanglement in the Pisonia canopy on Aride (Tyzack \& Volcere 1986), although this was rarely observed during our study period (maximum 2 to 3 birds). On Aride, sooty terns also breed at higher densities in open areas (Feare at al. 1997). We observed that sooty terns breeding in very dense forest areas become entangled in ferns and shrubs, and several birds were found dead every year (authors' pers. obs.). Also, redtailed tropicbirds Phaethon rubricauda land beside their own nest-site, where their movements are se- 
verely impeded by a large number of stems or higher fern cover (Clark et al. 1983). Therefore, forest cover on tropical seabird islands in the Indo-Pacific region may be important to understand habitat occupancy by seabird species nesting under woodland. Seabirds breeding under a forest canopy dominated by Pisonia are also at risk from its sticky seeds that adhere to their feathers and, if present in large quantities, prevent the birds from flying. During 12 yr of close monitoring, from 1995 to 2006, there were 2 yr of major fruiting that coincided with the roseate tern breeding season, 1995 (Ayrton 1995) and 2004 (Monticelli \& Ramos 2004), in which up to 60 adults were killed ( 5 to $10 \%$ of the annual breeding population). Also, many sooty terns and white-tailed tropicbirds Phaethon lepturus were observed dying from sticky Pisonia seeds. Clearly, birds breeding under a closed canopy will be more at risk from fruiting Pisonia than those breeding in clearings.

\section{Reproductive performance}

Breeding success was higher in the clearings than in the closed canopy area, indicating that forest clearings were of higher quality to breeding birds (Block \& Brennan 1993). However, in 2005, chick food delivery and adult body condition were similar between birds breeding in the 2 areas. Multiple indicators of habitat quality may not give the same response because habitat conditions favouring density, survival, body condition or reproduction may not be the same (Franklin et al. 2000).

Birds laid smaller clutches, started slightly earlier, and spread laying over a shorter period in the closed canopy area than in the clearing, which could be an indicator of higher parental quality or of older birds breeding in that area, because older and/or more experienced roseate terns on Aride seem to trade off clutch size and egg size for early laying (Rowley 1983, Ramos 2001, 2002b). Individual birds were presumably attracted to breed in the most familiar closed canopy locations and fell into an 'ecological trap' (Battin 2004), because this area was decreasing in quality.

The possible advantage conferred by early laying in the canopy quadrat was overridden by other factors. This includes habitat-related features, such as nestlings infested by Pisonia seeds in 2004, and/or wandering far from the nesting territory under nearby fern cover where they may become entangled. Also, in this area we found small chicks dying because of excessive wetting, resulting from heavy rain draining along small channels in the leaf litter in 2005, whereas in the clearings the quick regrowth of herbaceous vegetation prevented the formation of such drainage channels. Tick infestation levels did not differ signifi- cantly between the clearing and canopy quadrats in both years, although we noted a tendency for a higher proportion of infested chicks in the canopy area than in the artificial clearing (e.g. 67 vs. $43 \%$ in 2005). Peavey \& Lane (1996) showed experimentally that sub-adults of the tick Ixodes pacificus are sensitive to desiccation and that the mortality of developing sub-adult ticks may be higher in open, exposed grassland than in woodland. Thus, interpretation of the tick infestation pattern on Aride warrants additional years of monitoring, as our observations spanned only 2 yr. On Aride, ticks have a significant influence on chick growth and mortality (Ramos et al. 2001), and we suspect that the frequent relocation of breeding birds among years in relation to forest cover (present study) may reduce the impact of ticks on breeding success.

\section{Implications for colony management}

Our results suggest that a particular partitioning may occur in seabirds breeding under woodland, leading some individuals (presumably as a result of a high fidelity to the breeding site) to breed under a fairly closed canopy (i.e. same area in the colony as in previous breeding seasons). Forest clearings occupied by the terns develop into closed forest with dense fern and canopy cover within about $5 \mathrm{yr}$, forcing birds to move despite their presumed breeding site fidelity. The reasons behind the preference for forest clearings may simply lie in the fact that an enclosed canopy cover is likely to present some difficulties for the birds flying in and out from their nests. Natural openings are the result of windfalls that may also provide an important number of objects (e.g. branches that fall to the ground) that can be used for nest concealment, a strategy implicated in the protection of young chicks from attacks by adults (Ramos 1998). If clearings are not formed naturally, artificial clearings created within the area of the woodland colony are likely to be very attractive for roseate terns and other ground-nesting species, such as sooty terns. It is also important that the area around those clearings is not dominated by Pisonia grandis trees. Several small clearings the size of our experimental clearing (i.e. about $50 \mathrm{~m}^{2}$ ) seemed adequate because within a single smaller preferred area, nest densities may be so high that intraspecific aggression by adults on chicks increases, thereby lowering breeding success (Ramos 2003).

Acknowledgements. We are indebted to J. Cadbury, A. Skerrett, and the Scientific Committee of Island Conservation Society for permission to conduct our work on Aride. This study was funded by J. Cadbury (travel expenses to Seychelles), the Belgian Fonds Léopold III, and a doctoral grant to 
D.M. from the Belgian Government (SSTC, Action II-Contract WI-36-D03). We thank the forestry division of the Seychelles Department of Agriculture for assistance during vegetation manipulations in 2004. Our particular thanks go to the wardens of Aride, C. Self, M. Betts, D. Evans, and B. Sampson, for their valuable help and support during fieldwork. I. Bachy and Y. Laurent assisted in figure preparation, and their help is acknowledged. We also thank C. Feare and 2 anonymous referees for valuable comments on a previous version of the paper.

\section{LITERATURE CITED}

Ayrton V (1995) Roseate tern breeding season on Aride Island. Royal Society for Nature Conservation, Lincoln

Battin J (2004) When good animals love bad habitats: ecological traps and the conservation of animal populations. Conserv Biol 18:1482-1491

BirdLife International (2004) Sterna dougallii. In: IUCN 2006 Red List of Threatened Birds. Available at: www. iucnredlist.org. Accessed: 28 March 2007

Block WM, Brennan LA (1993) The habitat concept in ornithology: theory and applications. Curr Ornithol 11: 35-91

Blondel J, Dias PC, Maistre M, Perret P (1993) Habitat heterogeneity and life-history variation of Mediterranean blue tits (Parus caeruleus). Auk 110:511-520

Bock CE, Jones ZF (2004) Avian habitat evaluation: should counting birds count? Front Ecol Environ 2:403-410

Burger J, Gochfeld M (1988) Nest-site selection by roseate terns in two tropical colonies on Culebra, Puerto Rico. Condor 90:843-851

Castle GE, Mileto R (1994) Flora of Aride Island, Seychelles. Eco Tech, Shrewsbury

Clark L, Ricklefs RE, Schreiber RW (1983) Nest-site selection by the red-tailed tropicbird. Auk 100:953-959

Cody ML (1985) Habitat selection in birds. Academic Press, London

Collar NJ, Andrew P (1988) Birds to watch. The ICBP checklist of threatened birds. ICBP Tech Publ No. 8. International Council for Bird Preservation (ICBP), Cambridge

de Korte J (1984) Status and conservation of seabird colonies in Indonesia. In: Croxal JP, Evans PGH, Schreiber RW (eds) Status and conservation of the world's seabirds. ICBP Tech Publ No. 2. International Council for Bird Preservation (ICBP), Norwich, p 527-545

Englund SR, O'Brien JJ, Clark DB (2000) Evaluation of digital and film hemispherical photography and spherical densiometry for measuring forest light environments. Can J For Res 30:1999-2005

Feare CJ, Gill EL, Carty P, Carty HE, Ayrton VJ (1997) Habitat use by Seychelles sooty terns Sterna fuscata and implications for colony management. Biol Conserv 81:69-76

Franklin AB, Anderson DR, Gutiérrez RJ, Burnham KP (2000) Climate, habitat quality, and fitness in northern spotted owl populations in northwestern California. Ecol Monogr 70:539-590

Frazer GW, Canham CD, Lertzman KP (1999) Gap Light Analyser software: users manual and program documentation. Simon Frazer University, Burnaby, British Columbia, and the Institute of Ecosystems Studies, Millbrook, New York

Gochfeld M (1983) World status and distribution of the roseate tern, a threatened species. Biol Conserv 25: 103-125

Gochfeld M, Burger J, Nisbet ICT (1998) Roseate tern (Sterna dougallii). In: Poole A, Gill F (eds) The birds of North America, No. 370. Philadelphia, PA

Johnson M (2007) Measuring habitat quality: a review. Condor 109:489-504

Le Corre M, Cherel Y, Lagarde F, Lormée H, Jouventin P (2003) Seasonal and inter-annual variation in the feeding ecology of a tropical oceanic seabird, the red-tailed tropicbird Phaeton rubricauda. Mar Ecol Prog Ser 255:289-301

Maul AM (1998) Breeding biology and monitoring of 3 seabird species (brown noddy Anous stolidus, lesser noddy A. tenuirostris, roseate tern Sterna dougallii) on Aride Island, Seychelles, with special comments on breeding behaviour and biometrics of the brown noddy. PhD thesis, Karl-Franzens University, Graz

Monticelli D, Ramos JA (2004) The 2004 roseate tern breeding season on Aride. Royal Society for Nature Conservation, Lincoln

Peavey CA, Lane RS (1996) Field and laboratory studies on the timing of oviposition and hatching of the western black-legged tick, Ixodes pacificus (Acari: Ixodidae). Exp Appl Acarol 20:695-711

> Ramos JA (1998) Nest-site selection by roseate terns breeding on Aride Island, Seychelles. Colon Waterbirds 21:438-443

$>$ Ramos JA (2000) Characteristics of foraging habitats and chick food provisioning by tropical roseate terns. Condor 102:795-803

Ramos JA (2001) Seasonal variation in reproductive measures of tropical roseate terns Sterna dougallii: previously undescribed breeding patterns in a seabird. Ibis 143:83-91

Ramos JA (2002a) Roseate terns on Aride Island: the contribution of 19 years of monitoring to the conservation of an endangered species. Phelsuma 10:17-27

Ramos JA (2002b) Spatial pattern of breeding parameters in tropical roseate terns differ from temperate seabirds. Waterbirds 25:285-294

> Ramos JA (2003) Intraspecific aggression by roseate tern adults on chicks in a tropical colony. Waterbirds 26: 160-165

Ramos JA, del Nevo A (1995) Nest-site selection by roseate terns and common terns in the Azores. Auk 112:580-589

Ramos JA, Monticelli D (2007) Long-term studies on productivity of roseate terns and lesser noddies on Aride Island, Seychelles. Ostrich 78:443-447

- Ramos JA, Bowler J, Davis L, Venis S, Quinn J, Middleton C (2001) Activity patterns and effect of ticks on growth and survival of tropical roseate tern nestlings. Auk 118:709-716

Ramos JA, Maul AM, Ayrton V, Bullock I and others (2002) Influence of local and large-scale weather events and timing of breeding on tropical roseate tern reproductive parameters. Mar Ecol Prog Ser 243:271-279

Rowley I (1983) Re-mating in birds. In: Bateson P (ed) Mate choice. Cambridge University Press, London, p 331-360

Saliva JE, Burger J (1989) Effect of experimental manipulation of vegetation density on nest-site selection in sooty terns. Condor 91:689-698

Schreiber EA, Burger J (2001) Biology of marine birds. CRC Press, Boca Raton, FL

Scott-Mills G, Dunning JB, Bates JM (1991) The relationship between breeding bird density and vegetation volume. Wilson Bull 103:468-479

> Seddon PJ, Davis LS (1989) Nest-site selection by yelloweyed penguins. Condor 91:653-659

Sergio F, Newton I (2003) Occupancy as a measure of habitat quality. J Anim Ecol 72:857-865

Shealer DA (1995) Comparative foraging ecology of roseate 
and sandwich terns in Puerto Rico and its relation to breeding performance. PhD thesis, Rutgers, The State University of New Jersey, New Brunswick, NJ

Stonehouse B (1966) Egg volumes from linear dimensions. Emu 65:227-228

Tree AJ (2005) The known history and movements of the roseate tern Sterna dougallii in South Africa and the western Indian Ocean. Mar Ornithol 33:41-47

Tyzack SM, Volcere O (1986) The roseate tern Sterna dougallii on Aride Island, Seychelles: notes on the 1984 season.

Editorial responsibility: Stuart Bearhop,

Penryn, UK
Scopus 10:45-47

Warman SR (1979) The roseate tern Sterna dougallii arideensis on Aride Island, Seychelles. Bull Br Ornithol Club 99:124-128

Warman SR, Todd D (1984) A biological survey of Aride Island Nature Reserve, Seychelles. Biol Conserv 28:51-71

Williams B (1983) Some observations on the use of discriminant analysis in ecology. Ecology 64:1283-1291

Zar JH (1999) Biostatistical analysis, 4th edn. Prentice Hall International, Upper Saddle River, NJ

Submitted: June 21, 2007; Accepted: December 21, 2007

Proofs received from author(s): March 4, 2008 